\title{
Quaternary Glacioeustatic Sea-Level Highstands from the Bahamas: The Karst Signature
}

ABSTRACT

The Bahamian Archipelago, because of the young age of its surficial rocks, $100 \%$ carbonate geology, and tectonic passivity, has long been used as a test of Quaternary glacioeustatic sea-level highstand position and chronology. With the exception of Mayaguana Island, which displays slight vertical rotation to the south exposing much older units, fossil (the MIS $5 \mathrm{e} \mathrm{tim}$ indow, 120 ka. It has been argued that older corals formed either (Mis 7 ), or have been taken below 1. erc.). Flank margin cave position on average at 0 to $6 \mathrm{~m}$ eavation, 11, elc.). Flank igin interpretion for the caves. In contrast, some caves, primaily in Touthern Bahamas, display phreatic dissolution at elevations up to 17 m above sea level, and a stalagmite from Conch Bar Cave on the Caicos Plform was recently dated by U/Th to 266 ka. These observations . Bahamas. If so, where are the pre-MIS 5 e fossil corals and related subtidal deposits? An often overlooked aspect is the karst denudation te. Work on Guam in the western Pacific discovered $5 \mathrm{~m}$ of landscape . he Bahamas (and accounting for climatic differences) suggests that those older reefs are entirely denuded, and that the remaining sea-leve signature is preserved only in remnant flank margin caves, formed within he eolian high ground topograph
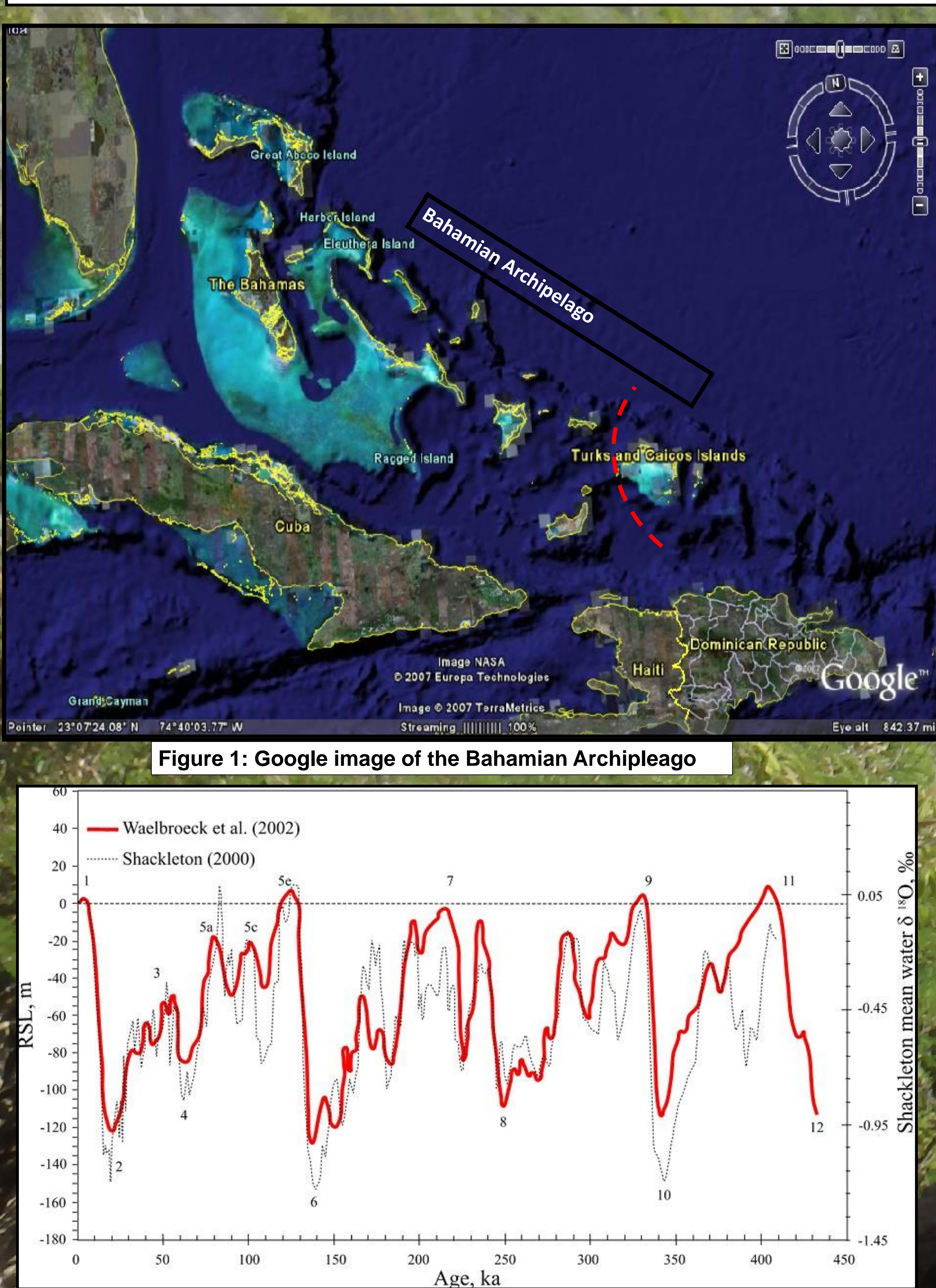

Figure 2: Glacioeustatic sea level curve for the last half-million years (Lascu, 2005)
Joan R. Mylroie and John E. Mylroie Department of Geosciences Mississippi State University jem2@msstate.edu

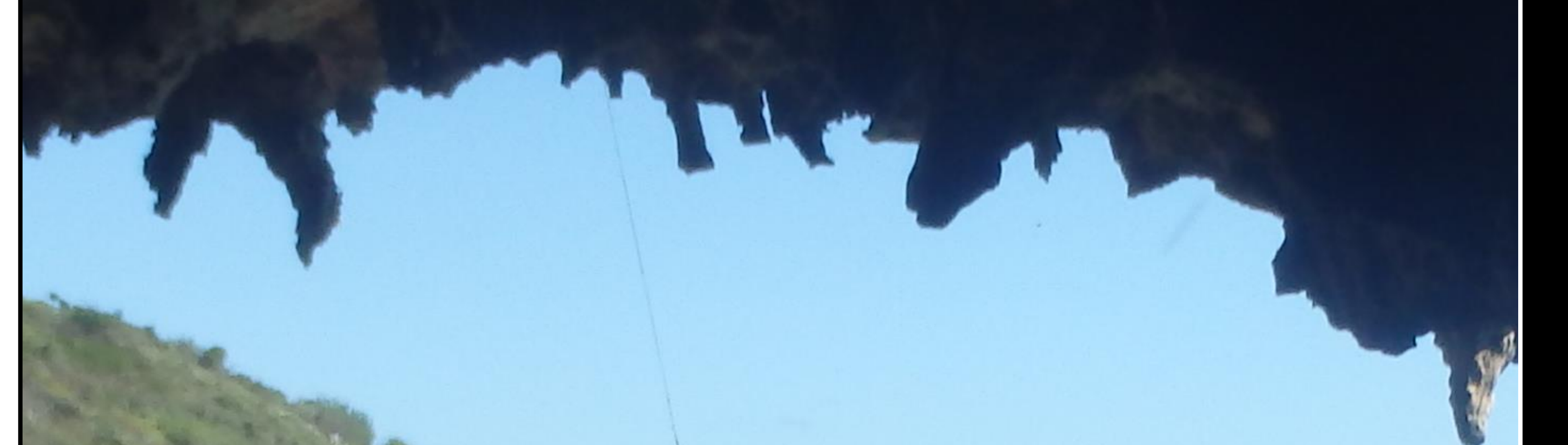

\section{西}
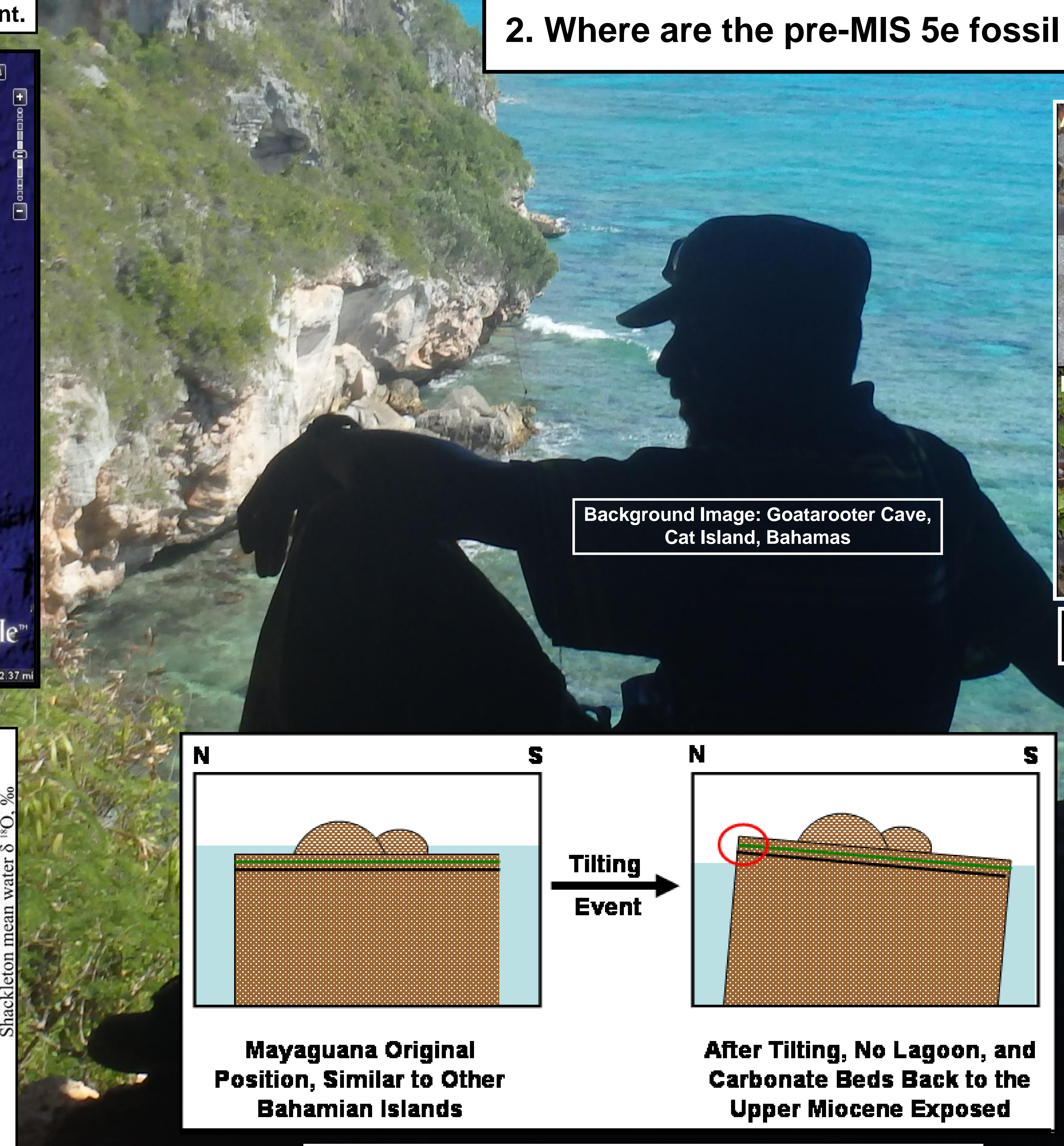

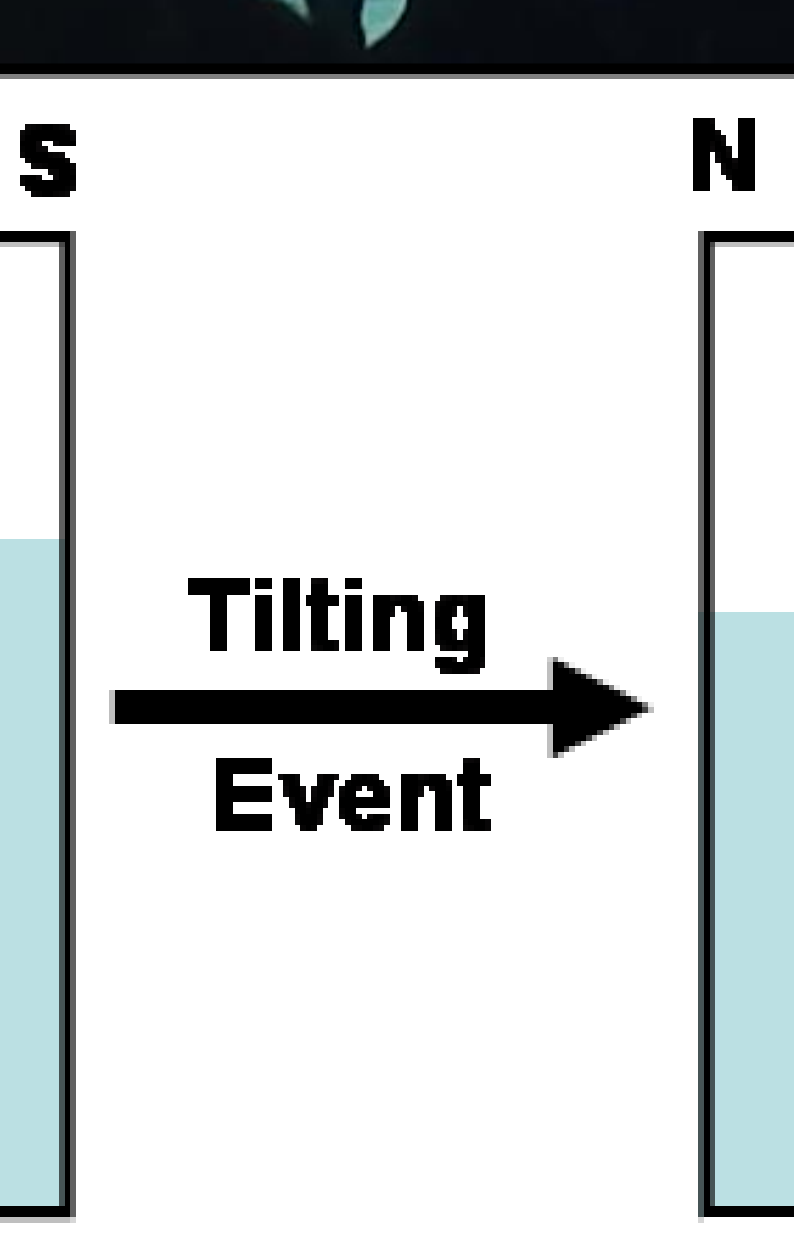
Mayaguana Original osition, Similar to Other Bahamian Islands

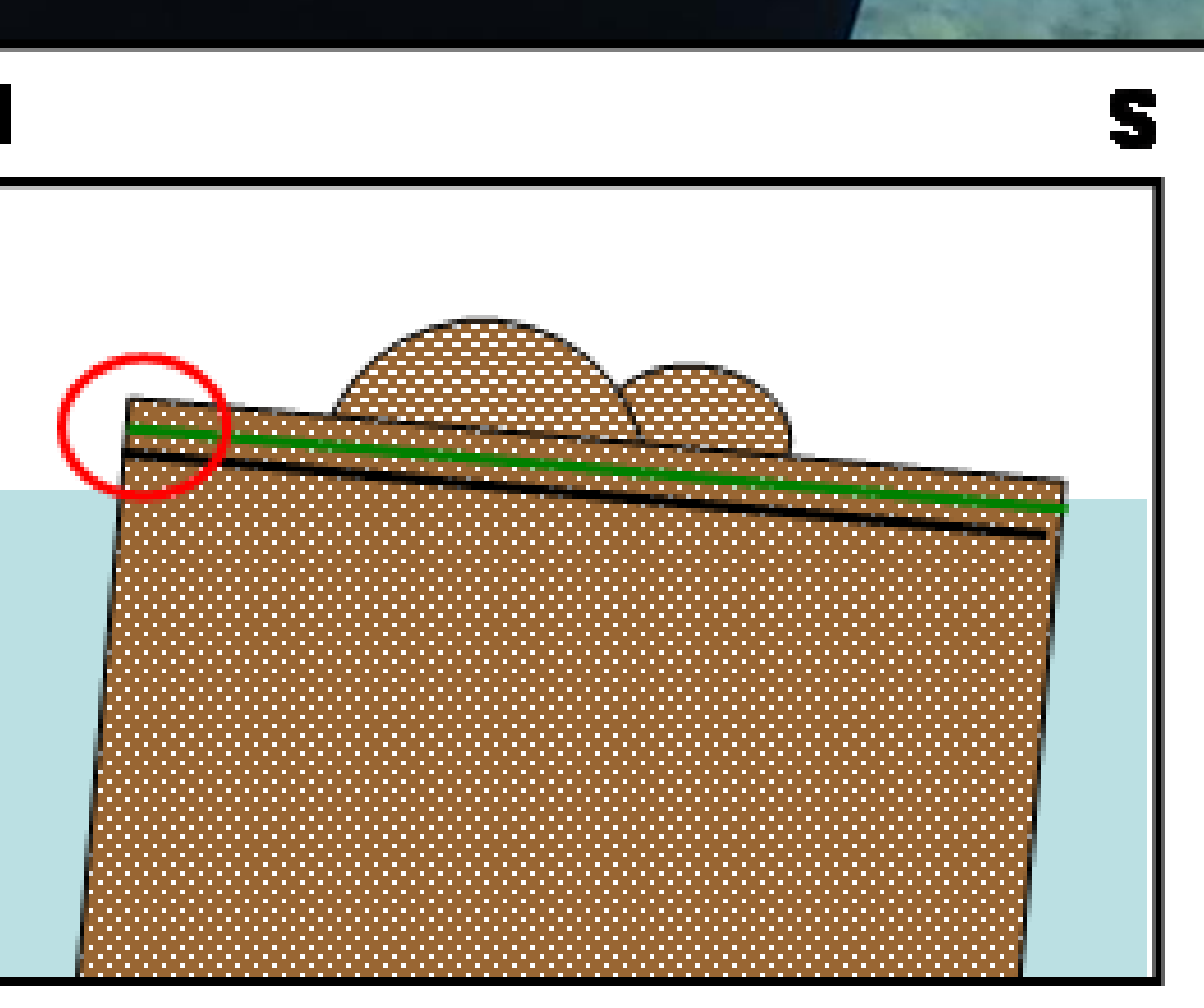

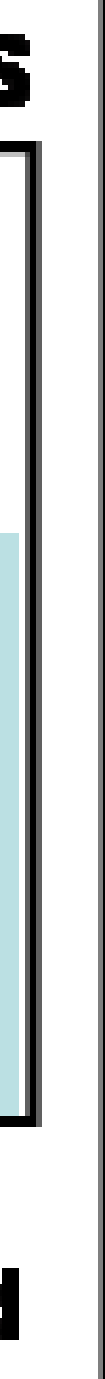

After Tilting, No Lagoon, and Carbonate Beds Back to the Upper Miocene Exposed

\section{OBSERVATIONS}

North and Central Bahamas:

1. All fossil corals date to MIS 5e (115-124 ka)

2. Flank margin caves mostly at 0 to $6 \mathrm{~m}$ asl

3. Caves contain stalagmites of ages $<120 \mathrm{ka}$ Southern Bahamas and Turks \& Caicos:

1. All fossil corals date to MIS $5 e$ (115-124 ka)

2. Flank margin caves commonly up to $12 \mathrm{~m}$ asl or higher

3. Caves contain stalagmites with ages up to $266 \mathrm{ka}$

\section{THE QUESTION}

1. The cave data suggest pre-MIS $5 \mathrm{e}$ uplift in the southern Bahamas

2. Where are the pre-MIS $5 e$ fossil coral and related lagoon deposits?
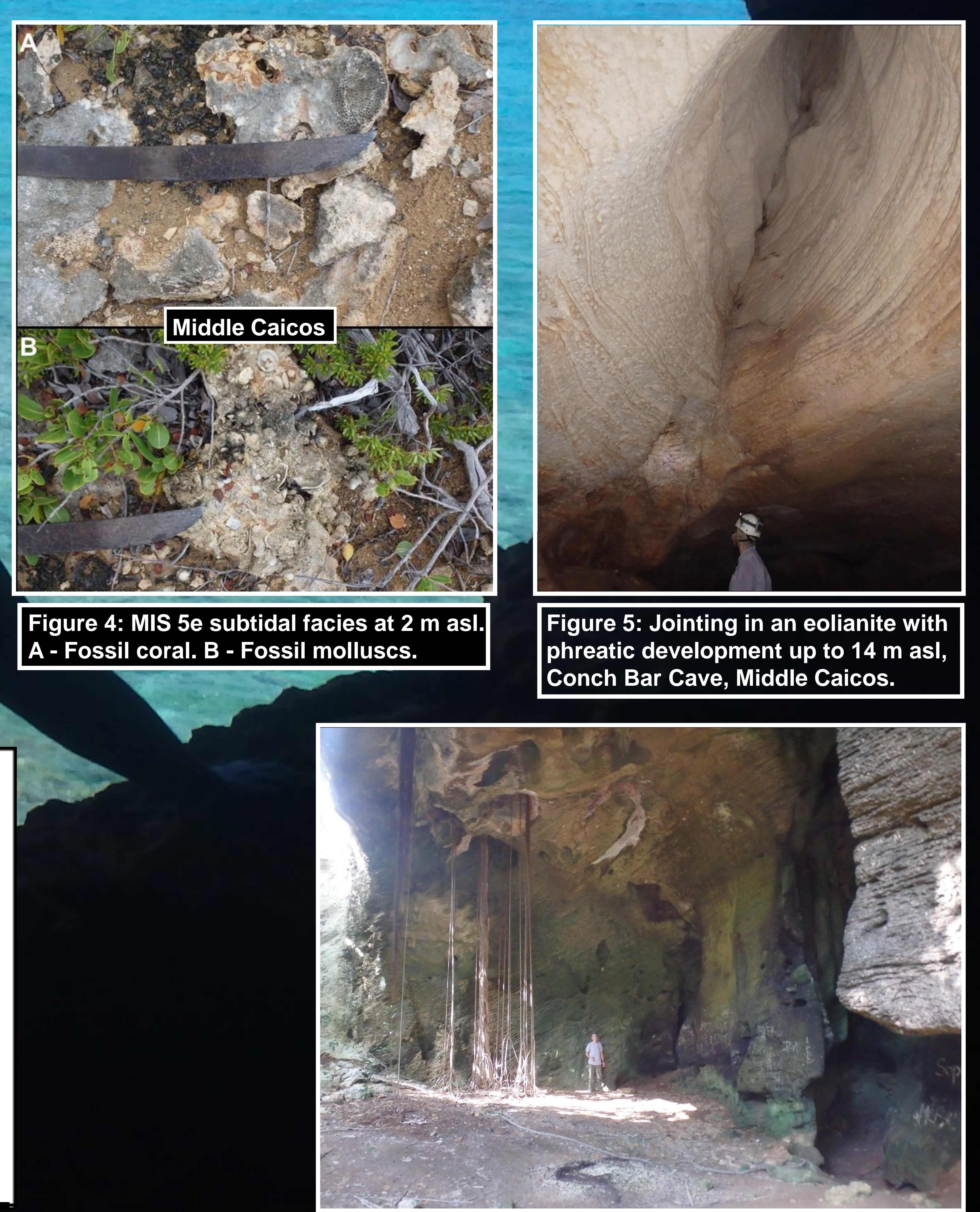

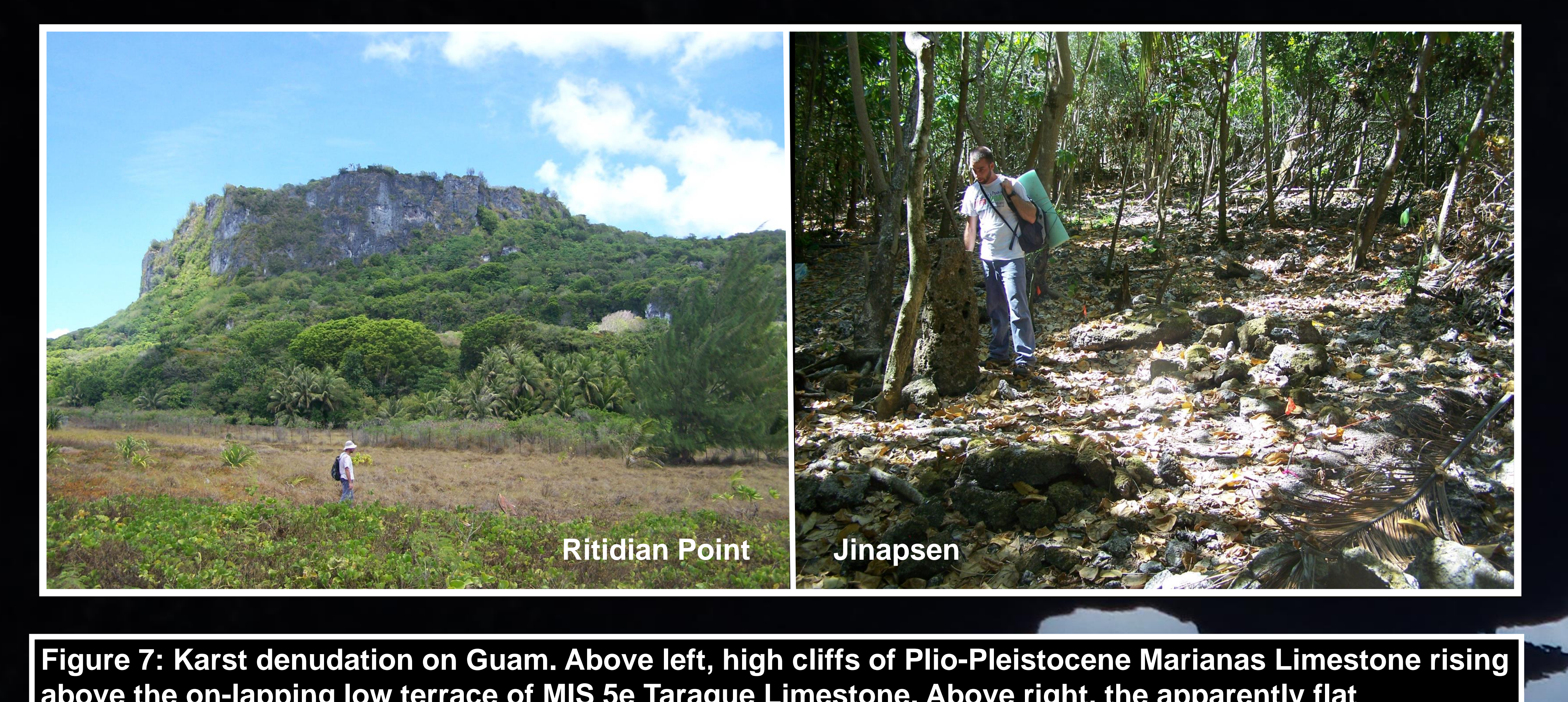
Figure 7: Karst denudation on Guam. Above left, high clifis of Plio-Pleistocene Marianas Limesto depositional plain of $120 \mathrm{ka}$ MIS $5 \mathrm{e}$ Tarague $\mathrm{E}$
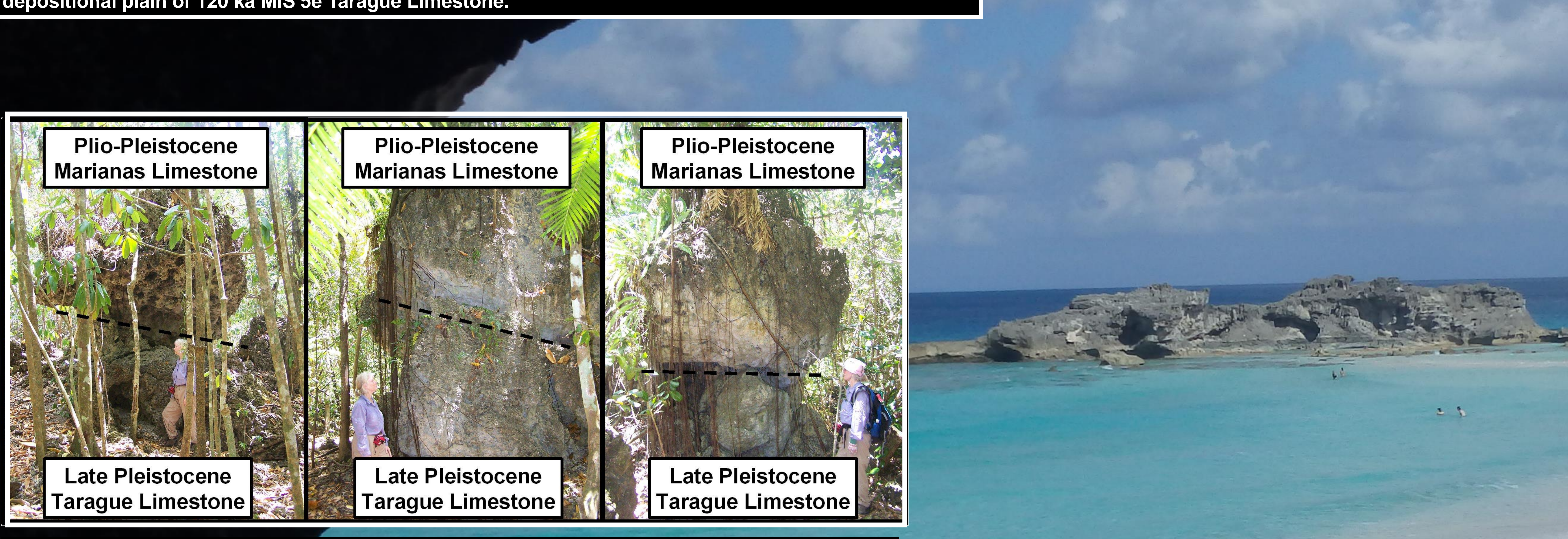

Figure 8 : karrentisch of Plio-Pleistocene Marianas Limestone boulders resting on top of
Tarague Limestone pedestals, indicating meters of denudation since MII $5 \mathrm{e}, \sim 120 \mathrm{ka}$.

\section{Calculated Denudation Rate \\ $50-120 \mathrm{~mm} / \mathrm{ka}$}

\section{$\left.{ }_{\mathrm{sm}}\right|_{\mathrm{sm} \mathrm{I}} \mathrm{S}$}

$8,000 \mathrm{~mm}: 125,000 \mathrm{yr}=0.064 \mathrm{~mm} / \mathrm{vr}$

Figure 9: The Guam data, utilizing both karrentisch and coastal notches (likely breached flank margin caves), coastal
indicates
years.

For the Turks and Caicos, the presence of MIS $5 \mathrm{e}$ fossi $4 \mathrm{~m}$ asl indicate Stalagmite U/Th ages older than MIS 5e, and flank 5e, with loss of pre to $17 \mathrm{~m}$ asl indicate uphit beiore deposits to karst denudation of up to $10 \mathrm{~m}$.

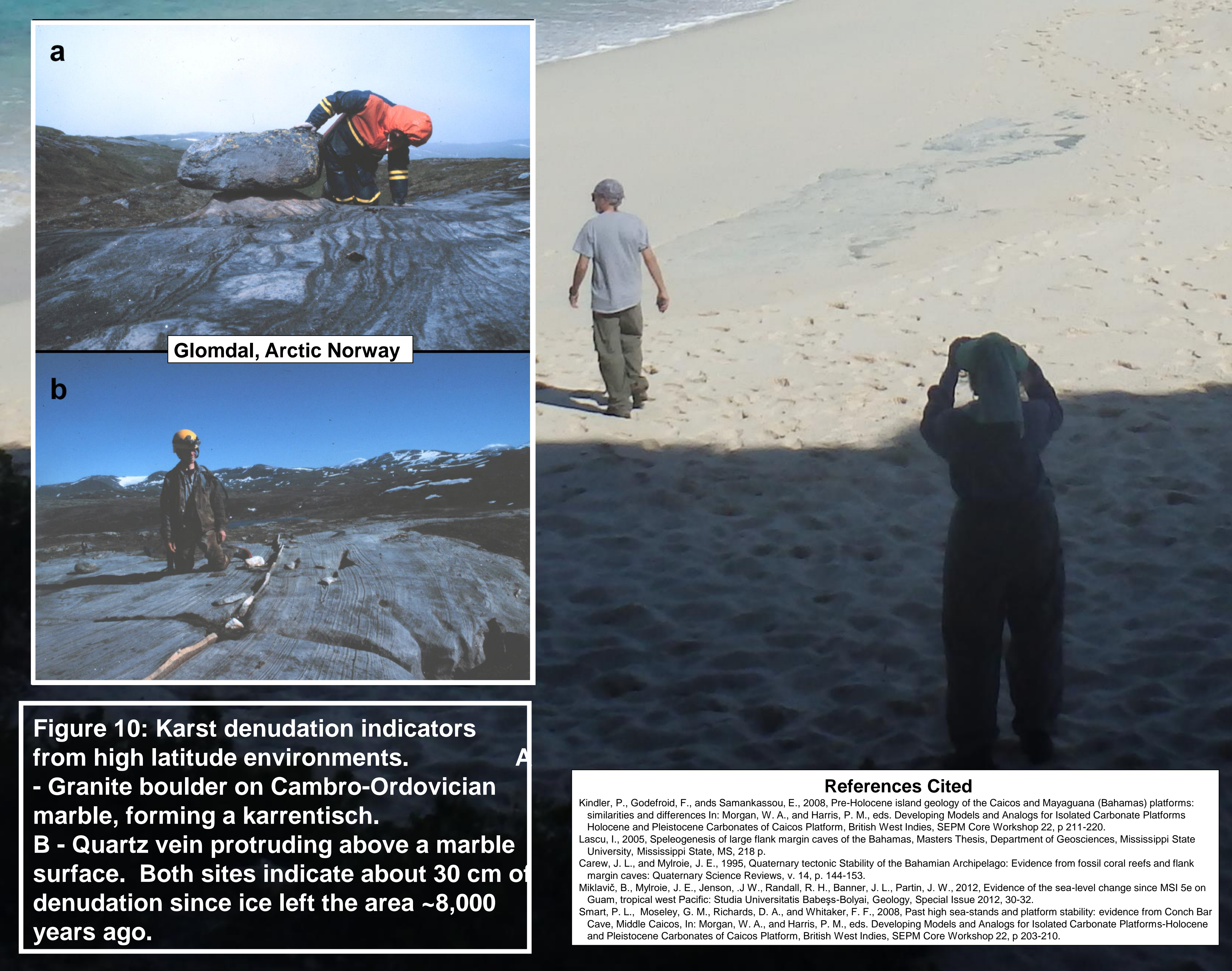

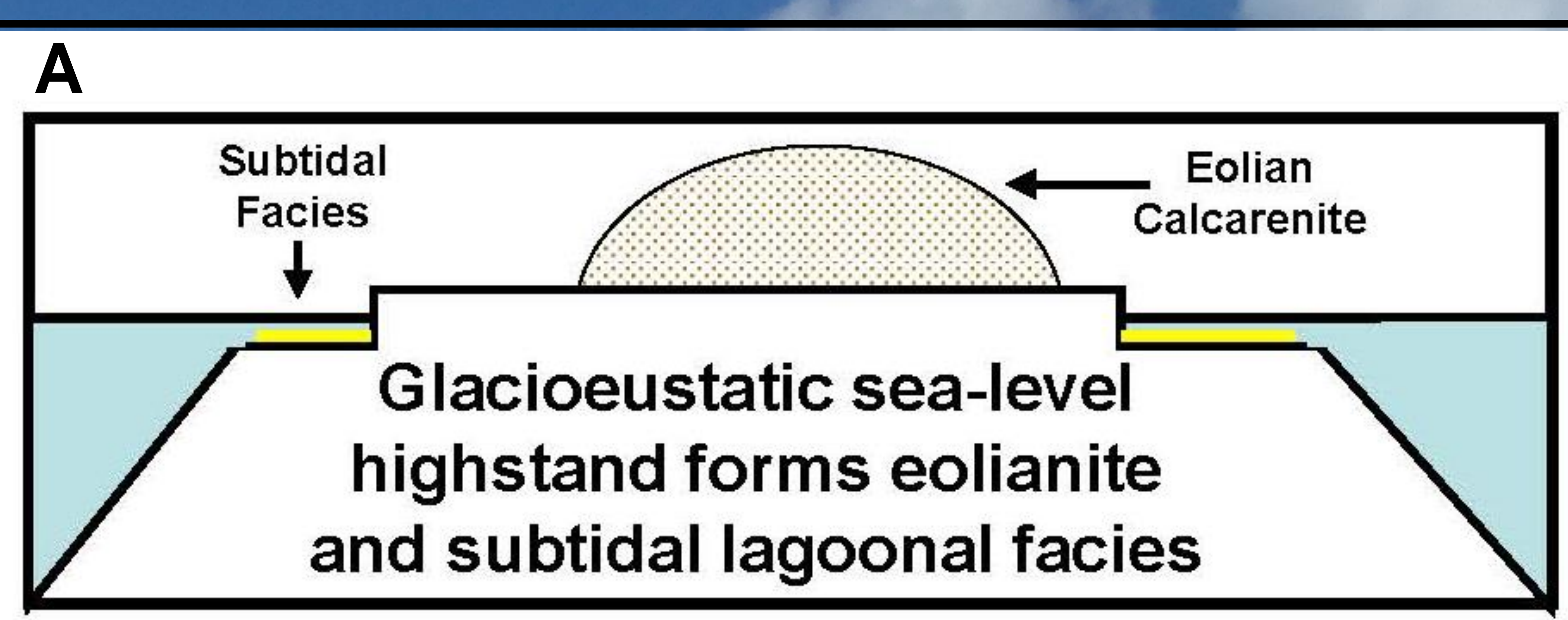

B
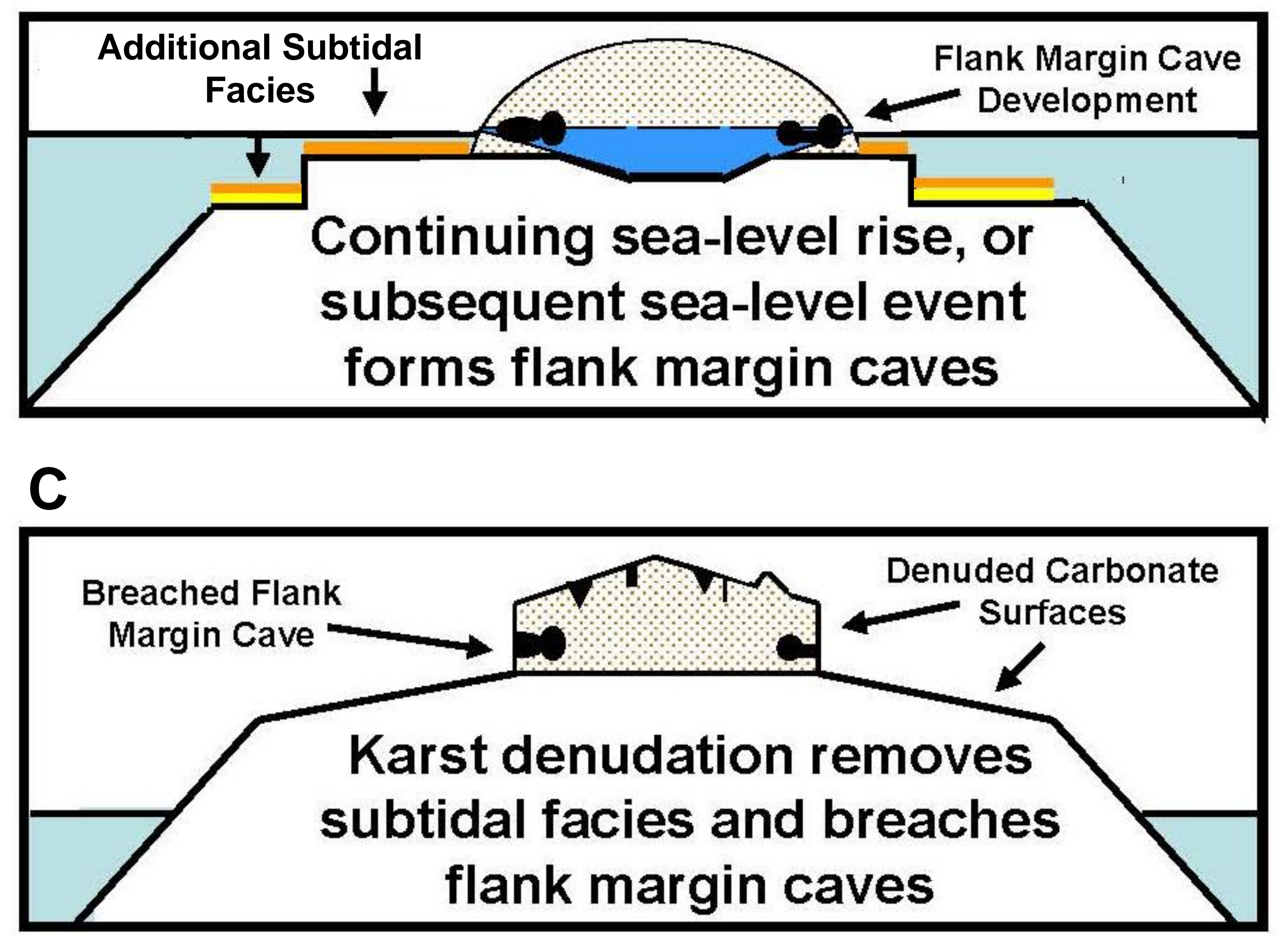

Figure 11: Conceptual model of how karst denudation can explain the observed geological features found in

A - During a sea-level highstand prior to MIS 5 e, platform flooding creates subtial facies and produces beach eolian calcarenite.

B-If the same highstand continues to a higher elevation, or during a subsequent sea-level highstand,
subtidal facies are deposited at higher elevations, and a fresh-water lens forms within the eolian calcarenite, subtidal facies are deposited at higher
and flank margin caves are produced.

C - During glacioeustatic sea-level lowstands (or during highstands that fail to flood the platform), karst margin caves are breached and exposed for access.

Pattorm uplift to bring the flank margin caves to elevations up to $17 \mathrm{~m}$ asl occurred after event $B$. Past

the entire Bahamas. The restriction of these high-elevation caves to the southern Bahamas implicates uplift.

\section{CONCLUSIONS}

Karst processes, by creating flank margin caves in the

subsurface, preserve a record of former sea-level position that

those very same karst processes remove from surface outcrops.

Acknowledgements: Nancy Albury, John Jenson, Michael Lace, and Blaz Miklavic for outstanding field assistance 